\title{
La reflexión "meta": una comparación entre los mecanismos irónicos de la comedia áurea y del Quijote
}

\author{
FEDERICA ZOPPI ${ }^{*}$
}

\begin{abstract}
Resumen
El estudio se adentra en el análisis de la función irónica y crítica que la reflexión "meta" desempeña en los ámbitos teatral y narrativo. En particular, se establece una comparación entre las estrategias metateatrales empleadas en las comedias áureas y el discurso metaliterario propuesto por Cervantes en el Quijote. Estos elementos autorreflexivos forman parte de un juego de distanciamiento y complicidad que crea una relación dinámica e interactiva entre autor, personajes y receptor. El principal vehículo de esta comunicación es el metapersonaje, que se proyecta fuera de los confines convencionales de la obra para dialogar con el espectador o el lector, hasta llegar a rivalizar con su mismo autor.
\end{abstract}

Palabras Clave: Quijote; metaliteratura; comedia; gracioso; metateatro.

Title: The "meta" reflection: a comparison between ironic strategies in Golden Age comedy and Don Quixote

\begin{abstract}
The study examines the ironic and critical function that the "meta" reflection plays in dramatic and narrative works. In particular, a comparison is made between the metatheatrical strategies used in Golden Age comedies and the metaliterary discourse proposed by Cervantes in Don Quixote. These self-reflexive elements form part of a ludic structure of detachment and complicity that creates a dynamic and interactive relationship among author, characters and receiver. The main vehicle of this communication is the meta-character, which is projected outside the conventional confines of the work to dialogue with the spectator or the reader and to question the author's control.
\end{abstract}

Key Words: Quixote; metaliterature; comedy; fool; metatheatre.

* Università degli Studi di Verona. federica.zoppi@libero.it / ORCID iD: http://orcid.org/00000003-2335-9430. 


\section{Cómo citar este artículo / Citation}

Zoppi, Federica (2017). "La reflexión "meta": una comparación entre los mecanismos irónicos de la comedia áurea y del Quijote», Anales Cervantinos. 49, pp. 35-58, doi: http:// dx.doi.org/10.3989/anacervantinos.2017.002.

En este estudio quiero adentrarme en el análisis de la función irónica y crítica que las estrategias "meta" pueden desempeñar tanto en el ámbito teatral como en el narrativo. El objetivo final es relacionar estos elementos metateatrales con algunas referencias metaliterarias en el Quijote, estableciendo un parentesco entre algunas estrategias metanovelescas y metateatrales. Mi hipótesis es que la influencia del teatro en la novela cervantina pueda percibirse también a la hora de establecer la relación con su lector, y que la actitud dinámica que se le requiere tenga una significativa correspondencia con la función del espectador del teatro y, en particular, del metateatro. Como el gracioso se burla de las convenciones del género, llamando la atención del espectador sobre estos automatismos, de la misma forma, Cervantes juega irónicamente con las funciones canónicas que se atribuyen a autor, personaje y lector en la narrativa.

Lo metateatral se configura como un elemento de gran interés a la hora de establecer la relación entre escenario y público, participando en un juego de distanciamiento y complicidad en que se funda el equilibrio de la representación y de su misma recepción. El elemento metateatral traduce en la escena la mirada del autor hacia el interior de su propia obra y hacia su procedimiento de escritura. El personaje metateatral separa claramente su punto de vista de la perspectiva de los demás personajes, asumiendo una postura crítica, que puede llegar a ser polémica. La ironía del mundo teatral se constituye precisamente en el engaño y en la conciencia de este engaño, que posibilita la convivencia de afirmación y negación ${ }^{1}$. Merece la pena citar las palabras de Hermenegildo (1995: 264), según el cual «la escena es el lugar de una ilusión de identificación por parte del espectador, pero al mismo tiempo es un conjunto de signos que denuncia el engaño de tal ilusión y señala su carácter ficticio, no real». Se trata de un juego con las apariencias con el cual se crea un complejo artificio artístico que capta el interés del auditorio para luego desvelar su mismo funcionamiento.

En esta condición de ambigüedad se constituye aquel sentido del humor al que apuntó Ortega y Gasset (1966: 382) cuando describió un arte - el del comienzo del siglo XX, que muchos rasgos comparte con la estética barrocaque «se hace broma», que se reconoce patentemente como farsa y que pone, como eje de su reflexión, el arte mismo y el desvelamiento de sus artilugios. Un arte que «en vez de reírse de alguien o algo determinado, [...] ridiculiza el arte» (Ortega y Gasset 1966: 382). El metateatro, entonces, fuerza la fron-

1. Fischer (1981) describió el metateatro precisamente como un artificio fundado en el equilibrio entre un polo positivo y uno negativo. 
tera entre ficción y realidad, experimentando su permeabilidad y la posibilidad, no solo de pasar de un lado a otro, sino también de existir contemporáneamente en las dos partes.

Esta posición privilegiada es uno de los rasgos fundamentales que definen la función del gracioso ${ }^{2}$ en la comedia áurea. El gracioso es el personaje al cual, en la mayoría de los casos, se le encomienda la tarea de expresar estas alusiones metateatrales ${ }^{3}$, que desvelan el artificio del cual él mismo hace parte. Con una aptitud irónica, además de cómica, el gracioso altera el orden de la comedia, revoluciona las normas establecidas, revela el artificio escénico y apunta con el dedo hacia lo fingido para burlarse de ello y de todos los que lo interpretan como verdadero. La metateatralidad, paradójicamente, llega a ser una forma de antiteatralidad, o, más bien, de anti-mimesis, que denuncia la falsedad de la representación y exhibe el engaño en que se funda ${ }^{4}$. El gracioso, entonces, fiel a su nombre y a su papel, «practica el artificio de burlar del teatro con medios teatrales» (Devoto 1979: 331). Lázaro Carreter (1987: 38) caracterizó al gracioso como el representante en la escena del público, «alter ego de todos y cada uno de los espectadores»; la raíz de su función dramática se hallaría en la posibilidad de que la franja de público socialmente más baja se identifique con él, con su pobreza e ignorancia. Según este planteamiento, el componente social del personaje del gracioso no se funda

2. Sobre el personaje del gracioso existe una bibliografía muy amplia; se remite a Lobato (1994) y Borrego Gutiérrez (2005) para un antología completa de los estudios sobre el tema. Sin embargo, quiero destacar el trabajo de Lázaro Carreter (1987), que se centró en el estudio del gracioso como figura que desempeña una función más que representar una personalidad y una psicología definida, rechazando la hipótesis de un origen social y realista del gracioso y subrayando la esencia convencional de la comedia en cada aspecto. Díez Borque (1976) asoció este aspecto convencional del gracioso con el hecho de que esta figura se define por su función literaria más que por sus rasgos sociales. Merece la pena mencionar también algunos trabajos posteriores que ofrecen una perspectiva global del personaje, en particular Gómez (2002 y 2005), García Lorenzo (2005) y el volumen dirigido por Díez Borque (2014), que ofrece varios estudios sobre la contribución de los autores del teatro prelopista a la construcción del personaje del gracioso y de los recursos cómicos que desencadena. Además, Gómez (2006) y Barone (2012) realizaron dos extensos estudios dedicados a la figura del donaire, respectivamente, en las comedias de Lope y en las de Calderón. Por lo que atañe a los graciosos de Calderón, indicamos también Sáez (2015).

3. Vélez-Sainz (2009) y Bustos Táuler (2014) exploraron los antecedentes de esta característica del gracioso, analizando las funciones metateatrales de las figuras cómicas de pastores del teatro prelopista, respectivamente en la obra de Bartolomé de Torres Naharro y Juan del Encina.

4. Hermenegildo (2003: 16) identificó en esta juntura la paradoja del metateatro: se desvela la naturaleza ficticia de la representación $\mathrm{y}$, al mismo tiempo, el teatro adquiere valor ontológico: «El TeT [teatro en el teatro] [...] siempre es un signo que envía al espectador la imagen de un mundo altamente teatralizado, de un mundo que induce a dudar entre la condición real o fictiva de lo que está presenciando. Si el público contempla, porque ha visto cómo se pone en marcha, el carácter ficticio de la obra enmarcada, reacciona ante la obra englobante como si estuviera ante la verdadera vida. Al poner de relieve el carácter fingido de la obra enmarcada, la obra englobante "adquiere las apariencias propias de la realidad" o, mejor, de "la verdad". Esta es una de sus virtudes. En el fondo el TeT puede ser un medio de dar credibilidad y verosimilitud al teatro. Aunque puede tener otra característica de efecto diametralmente opuesto. La obra enmarcada, por su carácter abiertamente fictivo, está modificando la percepción de la obra englobante y poniendo de relieve su condición noreal, su dimensión inventada, su consistencia estrictamente "teatral", fingida». Sobre este asunto, véase también Andres-Suárez (1997). 
en una mera representación o imitación, sino en la relación comunicativa con el público. En virtud de esta proximidad con el auditorio, el gracioso puede hacerse mediador entre los espectadores y el autor ${ }^{5}$, encargándose de hacer la obra más accesible para el público, incluso a través de alusiones metateatrales que revelan su funcionamiento y sus convenciones. Montesinos (1967: 62) fue entre los primeros estudiosos que puso de relieve este papel privilegiado del gracioso. Hernández-Araico (1986: 65) afirmó que «es precisamente mediante la ruptura de la ilusión dramática como el tipo bufonesco adquiere pues esa "gracia" que su nombre denota». Pailler (1980) señaló la técnica burlesca de autocrítica o referencias literarias en un alto porcentaje de las obras de Calderón, en 71 de las 117 comedias examinadas (65\%). En el 69\% de todos los casos, es el gracioso el que desempeña este papel que, aunque no se componga solo de explícitas referencias metateatrales, tiene el objetivo general de llevar a cabo «una desmitificación del espectáculo cómico» (Pailler 1980: 35), apuntando a elementos ajenos a la ilusión escénica. Los procedimientos dramatúrgicos son los que más se sujetan a la ironía calderoniana: el autor se muestra perfectamente consciente de la convencionalidad del teatro áureo e introduce comentarios técnicos sobre su propia actividad de autor y sobre la recepción de su teatro en el ámbito de sus mismas obras: «su reflexión teórica interrumpe la espontaneidad de la creación para introducir en la obra literaria la teoría de la literatura» (Morón Arroyo 1983: 229). Gómez (1999) atribuyó el mismo valor irónico a las referencias metateatrales que se encuentran en las comedias de Lope ${ }^{6}$.

Las alusiones metateatrales se burlan de las convenciones tradicionales de la comedia (Gómez 1999: 224) ${ }^{7}$, revelando los automatismos de su enredo, de su puesta en escena y también de las funciones asignadas a personajes y espectadores. La autoconciencia dramática es el principio fundador de estos recursos, así que, generalmente, se considera "metateatral" cada afirmación de la que se pueda deducir cierta conciencia por parte del personaje teatral de su propia pertenencia a un contexto de ficción literario-representativa, bien como actor bien como espectador ${ }^{8}$.

5. Sobre el papel de mediador del gracioso y su función en el proceso de recepción de la pieza véase Ruiz Ramón (2005).

6. Gómez (1999: 223) marcó una distinción entre las referencias metateatrales de valor irónico y las que implican un significado filosófico, una reflexión sobre el mundo y su relación con el contexto teatral, como ocurre en el teatro de Calderón. Serés (2011) estudió también la dimensión existencial de estos rasgos en la producción de Lope. Gómez (1999: 229), además, estudiando el teatro de Lope, coincidió con la atribución del propósito irónico a los comentarios críticos y autocríticos, pero sin limitar esta función de forma exclusiva al gracioso. Lo mismo había afirmado anteriormente Valbuena Prat (1941: 153-162).

7. Ya en José Prades (1963: 122-123) se encuentra una reflexión análoga, específica sobre las propiedades dramáticas del gracioso, que «se erige en censor de la comedia, y cuando menos lo esperamos, en medio de sus burlas, lanza unas alusiones críticas a la convención teatral en la que el mismo está participando».

8. La postulación teórica fundacional de la cuestión es el ensayo de Abel de 1963, del cual se emplea aquí la traducción italiana (Abel 1965). El discurso teórico que generó fue desarrollado en numerosas aportaciones, de las cuales señalamos, en particular, Forestier (1981), Hornby (1986), 
Este significado del discurso "meta" como resultado de la autoconciencia del personaje se puede extender también al ámbito de la narrativa cervantina: los recursos metanovelescos empleados por Cervantes en el Quijote pueden analizarse precisamente siguiendo esta línea como fundadora de su reflexión "meta" y del juego burlesco con las convenciones literarias, en particular por lo que atañe a las funciones de los personajes y del receptor.

El gracioso de la comedia áurea destaca en numerosos casos su percepción de tener una función precisa en la estructura propiamente técnica del cuento, de gestionarlo y manipularlo de forma transgresiva «como diablo de comedia» (Calderón 2011a: v. 2679, p. 207). El gracioso, efectivamente, es el que se mueve en el marco de la historia representada con aptitudes de «dramaturgo/ director ficcionalizado» (Sosa 2010: 64), el que se encarga de urdir enredos y trampas, dirigiendo la acción de los demás personajes. En La estrella de Sevilla Clarindo, al que a menudo ocurre que se le pidan versos «como si fuera maestro / de cortar o de coser» (Claramonte 2010: vv. 2166-2167, p. 265) ${ }^{9}$, declara explícitamente «intentar quiero un enredo» (Claramonte 2010: v. 2492, p. 283). La idea del enredo o del diseño creado por el gracioso se reitera en diferentes comedias: por ejemplo, en El desdén, con el desdén, Polilla se presenta como director de la acción, que "traza" el curso de los eventos «ello está trazado ya» (Moreto 1971: v. 1161, p. 136). Se puede recordar también al criado Mosquito de El escondido y la tapada que pregunta de manera aparentemente inocente «¿qué papel / me toca en esta comedia / del caballero escondido?» (Calderón 1944b: 460c). En Las bizarrías de Beli$s a$ se halla la misma situación, pero es la dama Lucinda quien se atribuye la autoría de la comedia, casi deslegitimando la posición del verdadero autor Lope, mientras que el galán escribe e imprime:

\author{
CONDE Mirad cómo la trazáis, \\ que resulte en vuestra gloria. \\ LUCINDA En toda amorosa historia \\ no es bien que el fin se presuma: \\ mujer soy, y será, en suma, \\ con que disculpada quedo, \\ mío de amor el enredo, \\ y vuestra será la pluma. \\ CONDE ¡Amor la imprima! (Vega 2004: vv. 1537-1544, p. 141).
}

Dällenbach (1994). Es inexcusable mencionar sobre este tema los trabajos de Hermenegildo (1995; 1996; 1999; 2002 y 2003). Merece la pena añadir también las contribuciones más recientes de Balestrino (2011), sobre el metateatro calderoniano, y de Rodríguez López-Vázquez (2011), que propuso una revisión terminológica de la cuestión.

9. No es cierta la atribución de la comedia a Andrés de Claramonte debido a la costumbre de los editores del siglo XVII de publicar volúmenes de comedias de varios autores bajo el nombre único de Lope de Vega, catalizador de la atención de los compradores. Alfredo Rodríguez López-Vázquez profundizó la cuestión de la autoría en la introducción a la edición que cito. 
Al analizar otra comedia lopesca, La portuguesa y dicha del forastero, Villarino (2001: 1341-1349) señaló la presencia de ocho enredos menores creados por los personajes; a estos se añaden diez relatos, siempre realizados por los personajes, que impulsan y movilizan la acción, además de dar cuenta de lo que no se puede llevar a la escena. Hermenegildo (1996: 130) notó que en El acero de Madrid la dama Belisa pone en marcha un plan que es auténtico teatro en el teatro, hasta el punto de que parece componer «una especie de protocuaderno de dirección» en el que abunda el léxico teatral que remite a cierta conciencia de los personajes de ser entes de ficción, con términos como invención, papel, ensayo, ficción, comedia, enredo y fingir.

Precisamente en virtud de esta propiedad de actuar como motor de enredos y director de la escena, el gracioso puede llegar a rebelarse contra la autoridad de su creador, criticando su labor. Se trata de intervenciones que, además de romper la ficción teatral, expresan la intención de refundarla a partir de un punto de partida interno a la misma obra. Esto lo hace, por ejemplo, Bato en Eco y Narciso:

$\begin{array}{ll}\text { BATO } & \text { ¿Oh Bato! } \\ \text { FEBO } & \text { ¿Tú mismo a ti te nombras, mentecato? } \\ \text { BATO } & \text { Pues, si no hay quien me nombre, } \\ & \text { ¿qué he de hacer? Y el estilo no os asombre, } \\ & \text { que el tiempo está tan necio e importuno } \\ & \text { que es menester honrarse cada uno } \\ & \text { (Calderón 1963: vv. 43-48, p. 4). }\end{array}$

Uno de los pasajes más explícitos en este sentido se localiza en Persiles y Sigismunda de Rojas Zorrilla, donde el gracioso Tarimón, obligado a quedarse en la escena un buen rato sin hablar, empieza así su discurso:

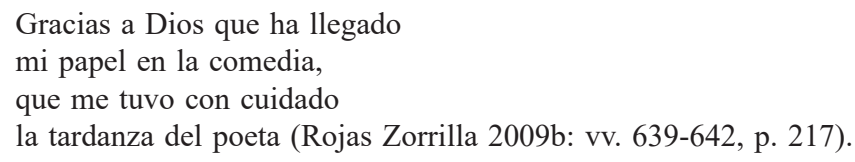

En otra obra de Rojas Zorrilla, Los celos de Rodamonte, se puede apreciar un largo parlamento del moro Barahúnda que describe su costumbre de conformarse a las clases de personas que encuentra. Solo los poetas no le permiten comportarse de esta manera:

\footnotetext{
Cuando estoy con Rodamonte, luego me rodamonteo y, si a Mandricardo hallo, a Mandricardo obedezco. Cuando encuentro a los franceses, me engabacho de sombrero $\mathrm{y}$, cuando encuentro a españoles, soy arrogante y soberbio.
} 


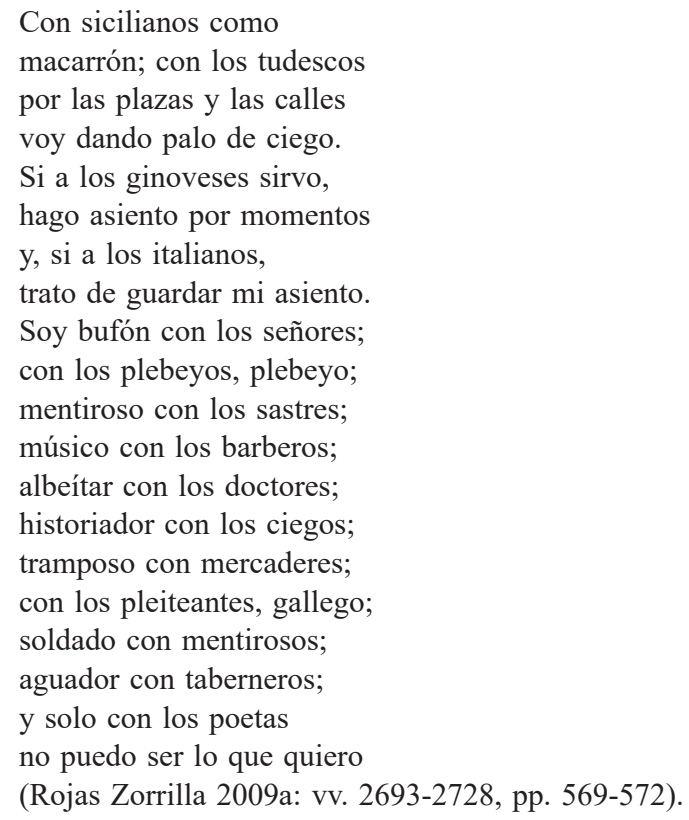

Este parlamento se interpreta inmediatamente como un ataque cómico a las diferentes categorías sociales, que se apoya en lugares comunes muy conocidos por el auditorio. Sin embargo, se puede atisbar que estos versos contengan también una referencia metateatral, es decir, la queja del gracioso contra los límites impuestos por la presencia del autor. El gracioso, en calidad de personaje ficticio, tiene que someterse a la voluntad del autor-poeta; Barahúnda se expresa como un actor que cambia su papel dependiendo de la ocasión: en él se hallan en potencia todas las formas que un hombre pueda adoptar y solo el autor tiene el poder de intervenir para limitar o dirigir el desarrollo de estas posibilidades. Rojas Zorrilla parece aplicar frecuentemente esta estrategia irónica que sugiere la posible rebeldía del personaje contra el comediógrafo, o, por lo menos, la facultad de criticarlo y de quejarse de sus decisiones ${ }^{10}$. Lo hace también la criada Beatriz en otra comedia, Donde hay agravios no hay celos, lamentando el hecho de que el autor no le otorgue la posibilidad de desahogarse a través de un soliloquio que normalmente no pertenece a la gama expresiva de los criados:

Yo solamente no tengo

a quien le cuente mis males.

Pues vaya de soliloquio,

que en cuantas comedias se hacen

no he visto que las criadas

lleguen a soliloquiarse (Rojas Zorrilla 2007: vv. 2849-2854, p. 404).

10. Para un estudio de los recursos metateatrales en el teatro de Rojas Zorrilla véase Sosa (2010). 
A través de estos ejemplos se delinea un rasgo especialmente interesante de algunas alusiones metateatrales, es decir, el juego irónico con las funciones convencionales de autor y personaje: el personaje parece rebelarse contra su mismo autor y manifestar una voluntad independiente. Es evidentemente un juego irónico que produce la ilusión de la autonomía del personaje mismo, puesto que se trata de entidades ficticias que no pueden imponerse a su creador.

En la obra maestra cervantina podemos encontrar una serie de alusiones que hacen referencia a este mismo intercambio de funciones. La crítica cervantina se detuvo pormenorizadamente en el estudio de los diferentes elementos y modalidades teatrales que se pueden detectar en la novela ${ }^{11}$; me parece que se podría añadir a la discusión también esta dimensión de lo metaliterario: presentándose como un elemento de novedad específico de la escritura cervantina, del cual casi no se detectan antecedentes en prosa ${ }^{12}$, es posible plantear la hipótesis de que esta técnica tenga su origen o, por lo menos, su inspiración en el ámbito teatral.

La novela cervantina, de hecho, abunda en referencias al proceso de escritura del texto: la mano extradiegética de Cervantes fragmenta su autoría en varias voces narrativas intradiegéticas, ninguna de las cuales es fidedigna; cada intermediario se distancia del texto atribuyendo la responsabilidad de la escritura $-\mathrm{y}$ de los eventuales errores - a los demás narradores. Se puede considerar esto como un segundo enredo, que traza la supuesta historia compositiva y editorial de la obra; en la novela, entonces, se detectan claramente dos líneas narrativas: en una es protagonista don Quijote, en la otra el Quijote. La existencia de este segundo enredo le permite a don Quijote ser a la vez personaje, autor y receptor de su historia ${ }^{13}$; consecuentemente le concede hacer referencia con espíritu crítico a la novela que protagoniza. La segunda

11. No me detengo en todos los numerosos estudios que se dedicaron a este tema; entre los más significativos señalo Casalduero (1970: 214-222.), McCurdy y Rodríguez (1980), Reed (1994), que se ocuparon de las diferencias entre la presencia del teatro en la primera y en la segunda parte. El cruce de los límites entre géneros literarios, entre novela y teatro, fue estudiado por Díaz-Plaja (1963); Van Doren (1962) se centró en el papel de actor que adquiere don Quijote a partir de su intención de hacerse caballero andante. Syverson-Stork (1987) y Reed (1994) estudiaron la relación entre el Quijote y los entremeses cervantinos. Casalduero (1970), MacCurdy y Rodríguez (1980), Martín Morán (1986: 27-46), Ynduráin (1969: 87-112) y, más recientemente, Ricapito (2003), Maestro (2005) y Badui de Zogbi (2008) identificaron algunos episodios de la novela donde es posible localizar de manera más evidente el influjo de técnicas teatrales.

12. Un ilustre antecedente de esta relación dialógica entre autor y personaje se encuentra en $L a$ Lozana andaluza (1528) de Francisco Delicado; en esta novela en forma de diálogo - que le debe mucho a la técnica teatral - el autor se pone en escena a sí mismo para conversar con uno de los personajes, formulando recomendaciones que orientan la lectura de la obra, con la consecuente ruptura de la línea cronológica narrativa. Imperiale (1994: 59) definió a Delicado como «el primer escritor renacentista consciente (75 años antes de Cervantes) de la pluralidad discursiva de la voz narrativa y de la especularidad del texto - auténtico laboratorio escritural- que se vuelca sobre sí mismo».

13. Me parece más adecuado definir a don Quijote como "receptor" de la primera parte, en vez de lector: a pesar de que la mayoría de los personajes de la segunda parte sean lectores de la primera, el mismo hidalgo no lo es de forma directa y conoce el libro solo a través de la mediación de los demás. 
parte se configura como determinante a la hora de explorar un nuevo abanico de posibilidades, que permiten que la multiplicidad de las voces internas se enriquezca de las aportaciones de los mismos personajes. La recepción de la novela se hace asunto interno de la misma obra y los personajes intentan orientarla según la idea que quieren transmitir de sí mismos.

Al comienzo de la segunda parte, el bachiller Sansón Carrasco informa a Sancho y don Quijote de la existencia de un libro que celebra sus aventuras - o desventuras. A partir de este momento, los dos quedan implicados en el proceso de revisión al cual Cervantes somete la primera parte de la novela, contribuyendo a la ruptura de la ficción. La ironía cervantina adquiere aquí un nuevo valor, convirtiéndose en un elemento estructurante de un sistema de distanciamiento que ya no implica solo a los autores (el real y los ficticios), sino también a los personajes, que intentan reivindicar su autonomía frente a la voluntad del supuesto autor, Cide Hamete. Don Quijote, de hecho, pone en duda las capacidades de historiador de Cide Hamete por su origen árabe:

Desconsolole pensar que su autor era moro, según aquel nombre de Cide, y de los moros no se podía esperar verdad alguna, porque todos son embelecadores, falsarios y quimeristas. Temíase no hubiese tratado sus amores con alguna indecencia que redundase en menoscabo y perjuicio de la honestidad de su señora Dulcinea del Toboso; deseaba que hubiese declarado su fidelidad y el decoro que siempre la había guardado, menospreciando reinas, emperatrices y doncellas de todas calidades, teniendo a raya los ímpetus de los naturales movimientos (Cervantes 1998: II, 3) ${ }^{14}$.

También Sancho expresa sus propias perplejidades - y su desconfianzarespecto el retrato que el historiador de la primera parte realizó de él:

- Eso es lo que yo digo también — respondió Sancho-, y pienso que en esa leyenda o historia que nos dijo el bachiller Carrasco que de nosotros había visto debe de andar mi honra a coche acá, cinchado, y, como dicen, al estricote, aquí y allí, barriendo las calles. Pues a fe de bueno que no he dicho yo mal de ningún encantador, ni tengo tantos bienes que pueda ser envidiado; bien es verdad que soy algo malicioso y que tengo mis ciertos asomos de bellaco, pero todo lo cubre y tapa la gran capa de la simpleza mía, siempre natural y nunca artificiosa; y cuando otra cosa no tuviese sino el creer, como siempre creo, firme y verdaderamente en Dios y en todo aquello que tiene y cree la santa Iglesia Católica Romana, y el ser enemigo mortal, como lo soy, de los judíos, debían los historiadores tener misericordia de mí y tratarme bien en sus escritos. Pero digan lo que quisieren, que desnudo nací, desnudo me hallo: ni pierdo ni gano; aunque por verme puesto en libros y andar por ese mundo de mano en mano, no se me da un higo que digan de mí todo lo que quisieren (Cervantes 1998: II, 8).

14. Pérez y Enciso Orellana (1999) proporcionaron una reflexión específica sobre el capítulo II, 3 . 
A partir de este punto de vista crítico manifestado por los personajes, se posibilitan las intervenciones que Sancho y don Quijote realizan para subsanar algunos olvidos o descuidos de la primera parte, precisando los puntos donde «anda errada la historia» (Cervantes 1998: II, 3): en II, 4, se corrige el disparate de la desaparición del rucio de Sancho, que, después de ser hurtado, vuelve a aparecer misteriosamente; además, don Quijote critica la inclusión de digresiones que considera superfluas, ya que amplían el texto con una materia demasiado heterogénea y dispersiva, que distrae de la fábula principal:

No sé yo qué le movió al autor a valerse de novelas y cuentos ajenos, habiendo tanto que escribir en los míos: sin duda se debió de atener al refrán: «De paja y de heno», etcétera. Pues en verdad que en solo manifestar mis pensamientos, mis sospiros, mis lágrimas, mis buenos deseos y mis acometimientos pudiera hacer un volumen mayor, o tan grande, que el que pueden hacer todas las obras del Tostado (Cervantes 1998: II, 3) ${ }^{15}$.

Don Quijote y Sancho toman distancia de sí mismos y se hacen observadores externos, rompen la ficción narrativa convirtiéndose en críticos que dialogan con el autor, precisamente como ocurre con los personajes que salen de la ficción escénica revelando el artificio teatral.

En la construcción de este enredo de referencias metanovelescas, el personaje de Sansón Carrasco tiene un papel muy significativo, haciéndose «portavoz de la realidad histórica de sus dos héroes» (Pérez y Enciso Orellana 1999: 115). En cuanto fuente de las informaciones sobre la difusión y recepción de la primera parte de la novela, representa también el motor que desencadena la reflexión "meta" de la segunda parte y que permite la intervención de Sancho y don Quijote en este diálogo. Merece la pena subrayar que la descripción física de Sansón apunta a rasgos que lo clasifican precisamente como un personaje esencialmente jocoso «muy gran socarrón; [...] de condición maliciosa y amico de donaires y de burlas» (Cervantes 1998: II, 3). Por lo tanto, la función metanovelesca de Sansón es coherente con su caracterización de personaje humorístico puesto que, como hemos visto, también al gracioso de la comedia áurea se le atribuye con frecuencia esta facultad autorreflexiva de valor irónico, que parece acompañarse a su actitud típicamente cómica. En este mismo capítulo, además, don Quijote recuerda que las expresiones cómico-humorísticas requieren una inteligencia y una discreción especiales: «Decir gracias y escribir donaires es de grandes ingenios: la más discreta figura de la comedia es la del bobo, porque no lo ha de ser el que quiere dar a entender que es simple». No hay que sorprenderse entonces si esta clase de personajes teatrales sabe manifestar cierta profundidad de pensamiento, hasta el punto de encomendarle la reflexión "meta", que revela una este caso a través de una supuesta intervención de Cide Hamete. 
conciencia de sí mismos y de los mecanismos de la comunicación literaria superior a la de los demás personajes.

Las propiedades específicas del texto autorreferencial permiten establecer un diálogo no solo entre personajes y autor/narrador, sino también entre personaje y receptor. En la comedia, los momentos que rompen la ficción escénica crean un enlace entre ficción y realidad: el personaje autoconsciente vive y actúa en el enredo sin olvidarse nunca de que se trata de ficción, creando, además, un puente directo entre el autor y el espectador. Hernández-Araico (1986: 62) subrayó que este recurso es un instrumento irónico del autor para dejar percibir su presencia sin hacerla patente. La comunicación metateatral, entonces, se constituye como continuidad que autoriza al personaje a salir de la obra y a adquirir una perspectiva externa que puede llegar a enlazarse con la posición autorial. Otra vez, esta función parece pertenecer de forma prioritaria al gracioso, que se proyecta fuera de la frontera del espectáculo, como si fuese portavoz del mismo autor ${ }^{16}$; esto ocurre, por ejemplo, al final de $L a$ dama duende:

$\begin{array}{ll}\text { COSME } & \text { Por no malograr el tiempo } \\ & \text { que en estas cosas se gasta, } \\ \text { pudiéndolo aprovechar } \\ \text { en pedir de nuestras faltas } \\ \text { perdón; humilde el autor } \\ \text { os le pide a vuestras plantas } \\ \text { (Calderón 2011b: vv. } 3109-3114, \text { p. } 280)^{17} .\end{array}$

En otras ocasiones, el gracioso parece asumir la función de ser portavoz de la misma comedia:
ROQUE
Con que dirá la comedia, aunque a Don Antonio pese...
TODOS Que para dama la hermosa para mujer la prudente (Calderón 1944a: 91c).

Este contacto con el auditorio se establece en los momentos más convencionales, como la conclusión de la comedia, que es el lugar típico que el

16. Los comentarios literarios de los graciosos de Lope y el hecho de que algunos de ellos se precien de ser poetas — como ocurre con Chocón en La niña de plata-y otros lleven precisamente el nombre de Lope —como en Amistad y obligación - llevaron a algunos estudiosos a identificarlos como proyecciones y satirizaciones del mismo autor, expresión de ironía hacia el propio papel de escritor. Véase también Ley (1954).

17. Por rigor filológico, merece la pena subrayar que estos versos finales aparecen con un cambio significativo en otras ediciones. La edición que consulto, así como la realizada al cuidado de Fausta Antonucci en 2006 para la editorial Galaxia Gutenberg y la de 1987 de Ángel Valbuena Briones para Cátedra, utiliza como texto base la princeps, publicada en 1636 en Madrid en la Primera parte de comedias de don Pedro Calderón de la Barca, y denominada tradicionalmente P. Otras dos ediciones del mismo año, la de Valencia (V) y la de Zaragoza (Z), proponen, entre las numerosas variantes de la tercera jornada, una versión distinta del cierre. 
autor aprovecha para dirigirse al oyente, para solicitar su aplauso y pedir un trato indulgente ${ }^{18}$. A menudo el gracioso es el que pronuncia la captatio benevolentiae, en la que se pide perdón por las faltas, consiguiendo del público una sonrisa que lleva al aplauso final. Sin embargo, intervenciones del gracioso aparecen también en contextos menos convencionales y en diferentes lugares de las comedias. En El desdén, con el desdén, por ejemplo, el gracioso Polilla, con un vocativo explícito al auditorio, formula una reflexión sobre los hechos representados:

Señores, ;que estas locuras ande haciendo una Princesa!

Mas, quien tiene la mayor, ¿qué mucho que estotras tenga?

Porque las locuras son como un plato de cerezas, que en tirando de la una, las otras se van tras ella (Moreto 1971: vv. 1775-1782, p. 171).

Se trata de una estrategia bastante común, la de implicar al público en los acontecimientos de la comedia llevándolo a reflexionar sobre ellos a través de interrogaciones:

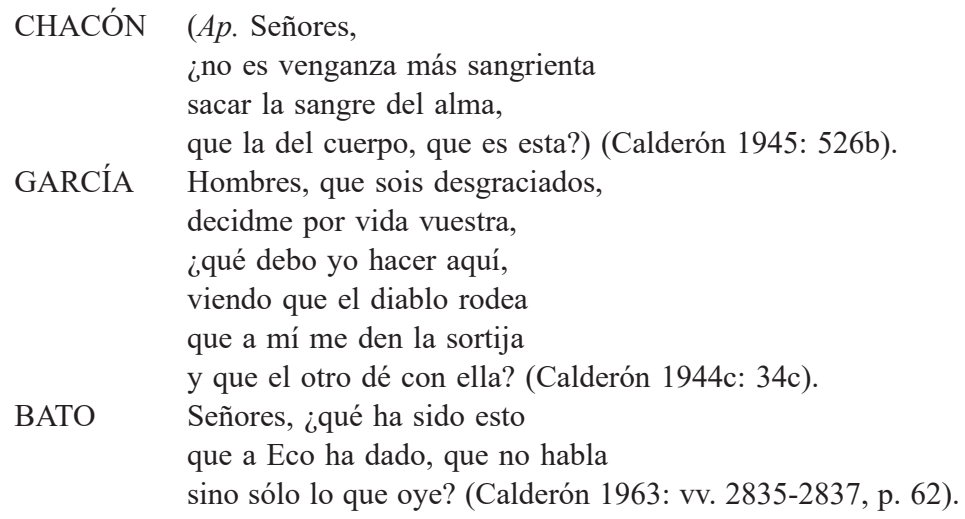

También la afrenta es veneno, de Rojas Zorrilla, incluye un parlamento de cuarenta y siete versos que el gracioso Barreto dirige al público:

Señores, hablemos claro

(esto quisiera saber)

¿hay quién quiera a su mujer?

Que será raro, y muy raro.

18. Lobato (2005) estudió los versos conclusivos de las comedias de Calderón en relación con el papel del gracioso que los pronuncia. Vara López y Vila Carneiro (2015) se dedicaron al estudio de los cierres convencionales de las comedias de Calderón, en relación con el artificio metateatral. 


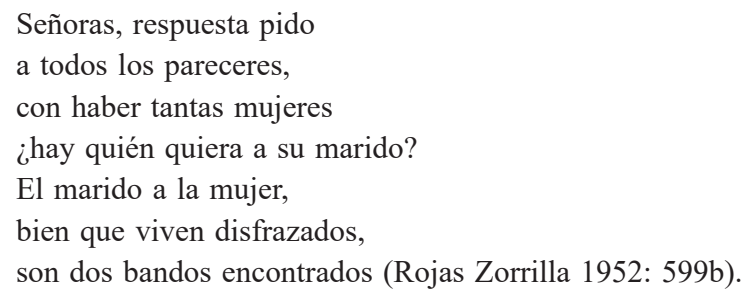

Otra estrategia eficaz para establecer un diálogo directo con el público es el uso de los apartes, que rompe el desarrollo de la obra y anima al espectador a hacerse intérprete de la acción ${ }^{19}$; en este sentido, un personaje que desempeña un papel particularmente interesante es el Bruto de Rojas Zorrilla en Lucrecia y Tarquino, un "loco cuerdo" que parece estar en escena precisamente para comentar la acción, ya que nunca participa activamente en ella: la mayoría de sus intervenciones son apartes, quince de las veintiocho totales, de modo que dialoga más con el público que con los demás personajes, instaurando una fuerte complicidad con el auditorio. Acaba por ser él mismo un espectador, desempeñando la función del coreuta y, al mismo tiempo, representando la voz teatralizada del autor (McCurdy 1976: 20).

Los personajes de la segunda parte del Quijote comparten la misma naturaleza fronteriza del gracioso teatral: situándose exactamente en el confín que separa realidad y ficción pueden comunicar tanto con los demás personajes, que tienen una perspectiva interna a la acción, como con el receptor, al cual le corresponde un punto de vista externo. Es más, como el mismo autor de la obra, los metapersonajes pueden asumir una perspectiva cambiante, que oscila entre las dos, hasta llegar a dialogar y competir con el mismo autor por el control de la obra.

Cervantes también le pide a su lector que reflexione sobre la obra, formulando un juicio personal que podrá ser, legítimamente, negativo: «Puedes decir de la historia todo aquello que te pareciere, sin temor que te calunien por el mal ni te premien por el bien que dijeres della» (Cervantes 1998: I, Prólogo). En II, 24, el lector está llamado a ejercer este libre albedrío crítico e intelectual sobre un caso concreto presentado en la novela, la aventura de la cueva de Montesinos, que se considera posiblemente apócrifa: «Tú, letor, pues eres prudente, juzga lo que te pareciere, que yo no debo ni puedo más». De esta manera el lector tiene la autoridad de evaluar la historia y formarse una opinión personal mientras el mismo autor rechaza la posibilidad de orientar el juicio del receptor y le reconoce una condición de completa autonomía intelectual. El lector queda así implicado bajo un punto de vista crítico en el texto; como ocurre con los personajes, el autor le atribuye un papel y una función precisa, que es la de relacionarse con el texto narrativo de forma activa. Esta participación crítica se hace casi física en la medida en que Cer-

19. Para el valor del aparte en el abanico de las alusiones metateatrales véase Hermenegildo (2003: 17). 
vantes parece ponerse al lado del lector para acompañarlo en los caminos de la narración, indicando lo que merece su atención, dirigiendo su mirada hacia las situaciones más interesantes y dejando suspendidas las que pueden esperar. En varias ocasiones se encuentra un "nosotros" inclusivo que hace referencia a acciones y desplazamientos realizados por el autor y el lector juntos, que se mueven entre las situaciones narrativas casi como si estuviesen en la escena teatral. Por ejemplo:

... pero dejemos con su cólera a Sancho, y ándese la paz en el corro, y volvamos a don Quijote, que le dejamos vendado el rostro y curado de las gatescas heridas (Cervantes 1998: II, 47);

... donde le dejaremos deseoso de saber quién había sido el perverso encantador que tal le había puesto. Pero ello se dirá a su tiempo, que Sancho Panza nos llama y el buen concierto de la historia lo pide (Cervantes 1998: II, 48);

... y don Quijote se quedó a caballo descansando sobre los estribos [...], donde le dejaremos, yéndonos con Sancho Panza, que no menos confuso y pensativo se apartó de su señor (Cervantes 1998: II, 10);

... dejémoslos pasar nosotros, como dejamos pasar otras cosas, y vamos a acompañar a Sancho (Cervantes 1998: II, 54);

... pero dejémosle aquí, que no faltará quien le socorra [...], y volvámonos atrás cincuenta pasos, a ver qué fue lo que don Luis respondió al oidor (Cervantes 1998: I, 44)

El lector parece moverse en el mismo tiempo y espacio narrativo compartido por los personajes, visualiza el desarrollo del enredo como si presenciara la acción, casi como el espectador de una comedia más que un lector. Este modelo de lector activo ${ }^{20}$, que se pone al lado del autor, parece desempeñar la misma función del espectador teatral y, en particular metateatral, que rompe las fronteras convencionales entre autor/personaje/espectador para implicarse en el enredo y dialogar directamente con el personaje o con el autor. Maestro (2005: 47) identificó en esto una peculiaridad de la escritura cervantina, la de proponer la «acción narrativa como espectáculo teatral», respecto a la cual los personajes que asisten se configuran a menudo como espectadores teatrales; en estos casos, el lector también adquiere la misma perspectiva de espectador, acudiendo a los hechos como si estuviera físicamente presente. Las tres funciones existen todas en el mismo plano y parecen compartir, en estas circunstancias, el mismo punto de vista interno a la narración.

Como se acaba de ver, Cervantes llama a su lector a ser crítico de la obra, a formular sus propias opiniones sobre el relato y sobre los acontecimientos contados, pero no se limita a esto: en una época en la cual los hábitos de lectura iban evolucionando hacia una fruición silenciosa del texto, intelectualmente más activa y reflexiva, Cervantes parece emplear también el modelo

20. Esta estrategia de implicación del lector puede relacionarse también con las nuevas costumbres culturales de la lectura silenciosa: véase Zoppi (2016a). 
de la recepción teatral para construir su imagen ideal de lector activo. Este lector se convierte también en un personaje que entra en el tejido narrativo de la obra y acompaña a los protagonistas en sus aventuras. En la segunda parte, además, los supuestos lectores de la historia escrita por Cide Hamete se hacen efectivamente personajes. Un ejemplo son los duques: «Los dos, por haber leído la primera parte desta historia y haber entendido por ella el disparatado humor de don Quijote, con grandísimo gusto y con deseo de conocerle le atendían, con prosupuesto de seguirle el humor y conceder con él en cuanto les dijese» ${ }^{21}$ (Cervantes 1998: II, 30). A la lectura siguió la comprensión de la historia y de la condición peculiar de don Quijote, acompañada por la intención se «seguirle el humor» secundando sus deseos. Esta intención se traslada en una burla cruel que ridiculiza a don Quijote en cuanto figura supuestamente "histórica" de la segunda parte y a sus ilusiones caballerescas; pero si se aplican estas mismas palabras a la lógica de la lectura de la primera parte de la novela, podemos entrever en ellas precisamente lo que Cervantes podría esperarse de su «discreto lector»(Cervantes 1998: I, Prólogo): el entendimiento de la historia y de su protagonista $\mathrm{y}$, consecuentemente, la decisión de acoger las locuras quijotescas con espíritu divertido, admitiéndolas como verdades aun a sabiendas de que se trata de ficciones literarias. El lector parece compartir el punto de vista de los duques: es víctima consciente de un engaño literario del cual saca su entretenimiento, manteniendo siempre la distancia crítica necesaria para discernir la verdad de la mentira ${ }^{22}$.

Lo que Cervantes busca a través de las referencias metaliterarias es la complicidad del receptor, tanto cuando crea un entretejido de autores y narradores mentirosos, como cuando atribuye a sus personajes la autoconciencia de la literariedad. Análogamente, las estrategias metateatrales son el artificio que, por excelencia, crea esta misma relación de cercanía intelectual con el espectador, que se siente englobado en la pieza, puesto que delante de sus ojos se descubren las convenciones de la comedia. El teatro se revela en su calidad de juego, del cual el receptor conoce las reglas: aceptar la representación, incluso participar en ella, pero con la conciencia del engaño que proporciona. Se trata de vivir el engaño, aprovechar el placer estético y el entretenimiento que conlleva, pero sin caer en su trampa de aparente realismo o veracidad ${ }^{23}$. Cervantes pone a su lector en la misma condición, rompiendo con las convenciones y los principios narrativos tradicionales y haciendo

21. Cursiva nuestra.

22. Lo que convierte a los duques en un modelo negativo es el hecho de no saber distinguir el plano literario de la primera parte del plano supuestamente histórico de la segunda. Durante el diálogo de II, 32, la duquesa exige por parte de don Quijote aclaraciones sobre algunos detalles de la primera parte, actuando como si formaran parte de una realidad histórica. La duquesa/lectora, convirtiéndose en duquesa/personaje, pierde su condición de receptor consciente y cae en el error de buscar la verdad de los hechos relatados en lugar de la verosimilitud de la narración.

23. Véase Abuín González (1996: 14-15) sobre el metateatro como «juego de estrategias constante dirigidas hacia la figura del espectador». El estudioso hace referencia también a Lotman (1985: 79) para la relación entre ficción literaria y juego. Sobre la estructura lúdica establecida por Cervantes en el Quijote, véase Zoppi (2016b: 207-218). 
burla de ellos, en primer lugar el de la verosimilitud. El autor ofrece al lector las herramientas para que pueda gozar de su cuento manteniendo la lucidez del distanciamiento: le pide, entonces, creer en su palabra con la conciencia de que es mentira. Solo un lector "discreto" podrá adentrarse en todos los caminos laberínticos ofrecidos por la novela cervantina, precisamente como el texto metateatral «comprende una figura de lector/espectador discreto con una participación mucho más activa de la que por sí le cabe en un texto teatral» (Balestrino 2011: 121-122).

Todas estas interferencias, entonces, permiten al receptor ver simultáneamente dentro y fuera del espacio narrativo y escénico, precisamente como los metapersonajes. Este sentido de simultaneidad, de hecho, es parte integral del concepto de ironía como figura retórica con la cual se suele decir algo expresando lo contrario ${ }^{24}$. Después de la creación del artificio, literario o teatral, el autor barroco se detiene en su desvelamiento para desenmascararlo; de esta forma parece aplicarse al mundo de las letras el método científico baconiano en un juego que se funda en la alternancia entre pars destruens (destrucción del mecanismo ficticio y engañador de la obra) y pars construens (refundación de la obra a partir de un punto de vista autoconsciente, compartido por metapersonajes y receptores) ${ }^{25}$. Las alusiones "meta" de hecho representan una puesta en discusión de la ficción a partir de un punto de vista interno: se desvelan las contradicciones del medio artístico y los mecanismos en los que se funda, pero sin que por eso el artificio deje de funcionar. Este conjunto de estrategias parece ser especialmente coherente en relación con el teatro del Siglo de Oro, cuyo propósito, según Rubiera Fernández (2005: 241), no era proporcionar un efecto de ilusión de realidad, sino crear una entorno festivo y simbólico: «El poeta dramático ahondaba en la naturaleza lúdica de su creación y con ella el espectador inteligente se daría cuenta de la ironía con la que el dramaturgo trata la propia materia teatral y seguramente esbozaría una sonrisa cómplice». Las alusiones "meta", efectivamente, pertenecen a un

24. En los tratados poéticos de los siglos XVI-XVII normalmente la ironía se considera solo como artificio retórico. Por ejemplo, según la definición de López Pinciano (1998: 243) se está ante una figura de ironía «cuando por un nombre queremos significar la cosa contraria de lo que él propiamente significa, como para decir que uno es profano, le decimos "el santo"». Análogamente, Carvallo (1997: 334) afirma que la ironía surge «cuando decimos uno, y se entiende lo contrario», describiéndola, además, como una «especie de alegoría que con palabras alaba, y por las circunstancias vitupera y afrenta».

25. El fundamento del método científico elaborado por Francis Bacon preveía precisamente la aplicación de una pars destruens, para demoler los antiguos convencimientos erróneos que representan puras ilusiones; el filósofo los definió idola y abrazaban convicciones diferentes, a partir de la excesiva importancia que el ser humano le otorga a la experiencia sensible, hasta los prejuicios educativos y sociales, para llegar a los errores debidos a la falacia del lenguaje y de las pasadas doctrinas filosóficas. A esta fase del pensamiento seguía la pars construens, un método inductivo que permitía la construcción de una nueva forma de saber más firme y verificada. Sobre la importancia de la cuestión metodológica en el Barroco y la necesidad de distinguir entre realidad y apariencia, véase Gambin (2001) y Blanco (2004), que estudiaron la cuestión en su relación con la filosofía de Baltasar Gracián. 
conjunto de técnicas antimiméticas que le permiten al receptor tomar cierta distancia intelectual con respecto a la realidad representada.

En la obra maestra cervantina se observa la misma tendencia lúdica, un juego con las convenciones que desatiende la verosimilitud histórica del texto $^{26}$. El hallazgo del supuesto manuscrito que transmite la historia de don Quijote le sirve a Cervantes para parodiar las pretensiones históricas de los libros de caballerías; al mismo tiempo es también el artificio fundador del juego metanovelesco, con el cual Cervantes crea un cruce de voces narrativas que se refieren al proceso de escritura de la obra, hasta llegar a implicar a los personajes. El autor nunca le permite al lector olvidar que el relato representa el resultado de su fantasía poética y que la verdad que le presenta delante de los ojos tiene un valor estético, y no histórico, puesto que «la ficción debe buscar su verdad y su legitimidad en sí misma, y no en referentes externos» (Miñana 2002: 174). El lector, como el espectador teatral, existe dentro y fuera del texto, vive momentáneamente en el mundo de la narración sin perder el contacto con la realidad, es decir, sin que le ocurra lo que le ocurrió a don Quijote con los libros de caballerías. El discurso "meta", entonces, tiene precisamente esta función de ofrecer una visión dislocada (Hornby 1986: 32), gracias a la cual el receptor entiende la obra como producto de ficción artística, sin olvidarse de la perspectiva y del tiempo históricos que lo engloba.

Para concluir, añadimos otra reflexión, procedente de la pintura barroca, sobre la propiedad de las figuras cómico-ridículas de relacionarse con el espectador: analizando los retratos de bufones realizados por Velázquez entre 1633 y 1648 , se nota que en los dos cuadros que representan a don Juan Calabazas, el bufón se presenta con los ojos estrábicos, rasgo que apunta a una deformidad típica de las figuras cómico-carnavalescas, compartida también por el pícaro cervantino Ginés de Pasamonte ${ }^{27}$. El estrabismo de los sujetos pictóricos, efectivamente, se configura como una inclinación a "mirar hacia fuera", a salir del marco del cuadro para proyectarse hacia el mundo exterior. El bufón parece observar dos puntos contemporáneamente, según dos perspectivas, con un ángulo visual que le permite ver más allá de los límites tradicionales ${ }^{28}$. El acto artístico, entonces, traspasa las fronteras que lo cierran en un contexto aislado y desborda, creando un continuum espacial y temporal

26. Varios estudios se adentran en la compleja cuestión de la verosimilitud cervantina. El análisis de Riley (1989: 278-307) sigue siendo una de las aportaciones imprescindibles. A esta podemos añadir otras contribuciones significativas, por ejemplo las de Percas de Ponseti (1975: I, 22-25), MartínezBonati (1995: 5-27) y Montero Reguera (1997: 79-82). Más recientemente, merece la pena señalar a Barbagallo (2001), Miñana (2002), Martínez San Juan (2004), Núñez Ronchi (2005) y, en particular Pérez (2011) para la relación entre los conceptos de verosimilitud y de credibilidad textual.

27. El galeoto se describe como «un hombre de muy buen parecer, de edad de treinta años, sino que al mirar metía el un ojo en el otro un poco» (Cervantes 1998: I, 22).

28. Strappini (2003: 12-24), en su estudio de estas pinturas, asoció estos rasgos de deformidad física con una correspondiente deformidad interior, interpretándolos como índices de locura. Ruffinatto (1985: 87-88), en cambio, consideró el estrabismo de Ginés de Pasamonte como un atributo superfluo, que no es índice de calidades interiores, al contrario de la gordura del ventero, que es manifestación de su carácter pacífico. 
con el ambiente que lo rodea ${ }^{29}$, proyectándose hacia el espectador, que queda incorporado en la representación como elemento activo y vital. Se trata de un rasgo que Orozco Díaz (1962: 427) identificó como típico de la estética barroca, pertenece al teatro, pero es también tendencia por la cual se «concibe en general la obra de arte no como algo aislado e independiente, sino enlazándose clara y sutilmente con el medio ambiente o paisaje $\mathrm{y}$, sobre todo el contemplador». En el Quijote se percibe la misma tendencia teatral hacia la construcción de una continuidad fluida entre universo del relato y universo del receptor; este enlace se convierte en un eje alrededor del cual se plantea una reflexión sobre la misma obra literaria: el lector, en cualquier momento, puede entrar en la historia y hacerse personaje, como efectivamente sucede con los duques y los demás personajes de la segunda parte, que fueron lectores de la primera. De la misma manera, el personaje puede salir parcialmente del universo ficticio para hacerse lector y crítico de sí mismo. El juego de perspectivas entre narradores ficticios y el consecuente juego de intercambio entre las funciones de autor/personaje/lector pone al receptor de la novela en el mismo lugar en el que se halla el espectador teatral, o mejor, el espectador de lo metateatral, que se encuentra en el umbral de realidades diferentes, en esa zona suspendida entre realidad y ficción.

Es frecuente que las figuras cómicas - teatrales, literarias y figurativasdesempeñen su poder transgresivo también en este sentido irónico, desquiciando las relaciones convencionales entre autor, personaje (o sujeto) y receptor para crear un entorno espacial y temporal continuo, un plano artístico tridimensional que implica a los tres. El gracioso y don Quijote encarnan perfectamente esta "visión doble", gracias a la cual el personaje mira "hacia dentro", hacia la esencia del engaño artístico para desvelarlo "afuera", al público lector o espectador, a la manera de la mirada estrábica de los bufones de Velázquez. Bajo este punto de vista, es posible notar que la concepción del espacio barroco como algo continuo y permeable, donde el espectador solo tiene que dar el último paso para entrar dentro de la obra, se hace fundamental para el desarrollo de la reflexión "meta" en la época, que aprovecha este

29. Orozco Díaz (1969: 39-43) profundizó su estudio sobre este «sentido de continuidad espacial y desbordamiento expresivo», o «expresión desbordante», subrayando sus efectos en el arte figurativo; merece la pena recordar, en primer lugar, las pinturas de Velázquez, que enlazan la obra con el ambiente del espectador, arrastrándolo dentro del cuadro mismo y dejándose condicionar por él: «su aspiración suma será hacer que el cuadro no sea cuadro, sino un ámbito espacial que limita el marco como si fuese una puerta a través de la cual se puede salir y entrar; o, si queremos extremar la relación, como si fuese la embocadura de la escena teatral». Igualmente «desbordante», y quizás de manera aun más visible, es la escultura barroca, sobre todo la de tema religioso, que conlleva, con esta estrategia, un nuevo y hondo sentimiento de patetismo. Limentani Virdis (1981: 59), al estudiar los efectos de mise en abîme en la pintura de interiores flamenca y holandesa, señaló el carácter narrativo de este artificio, que apunta a la creación de un cuento. La validez de los procedimientos narratológicos literarios en ámbito pictórico fue propuesta también por Segre (1979) y se halla, según Dällenbach (1994: 12) en la misma postulación del concepto de mise en abîme creado por André Gide en 1891: la mise en abîme sería un instrumento de reflexión sobre la obra, que destaca su misma estructura formal sin ser específica de la sola literatura. La relación entre Cervantes y Velázquez fue analizada también por Hatzfeld (1964). 
sentido de simultaneidad de tiempos y lugares diferentes para echar una mirada autocrítica a las funciones convencionales de los participantes en la comunicación artística, con espíritu irónico y jocoso, hasta delinear una nueva poética de la recepción literaria, que abraza teatro y novela, fundada en la autoconciencia del metapersonaje que consecuentemente se transmite al receptor.

\section{FUENTES}

Calderón de la Barca, Pedro (1944a). ¿Cuál es mayor perfección?, en Juan Eugenio Hartzenbusch (ed.), Obras de don Pedro Calderón de la Barca, vol. I. Madrid: Atlas (Biblioteca de Autores Españoles, t. 7), pp. 69-91.

Calderón de la Barca, Pedro (1944b). El escondido y la tapada, en Juan Eugenio Hartzenbusch (ed.), Obras de don Pedro Calderón de la Barca, vol. I, Madrid: Atlas (Biblioteca de Autores Españoles, t. 7), pp. 459-480.

Calderón de la Barca, Pedro (1944c). Saber del mal y del bien, en Juan Eugenio Hartzenbusch (ed.), Obras de don Pedro Calderón de la Barca, vol. I. Madrid: Atlas (Biblioteca de Autores Españoles, t. 7), pp. 20-35.

Calderón de la Barca, Pedro (1945). Dar tiempo al tiempo, en Juan Eugenio Hartzenbusch (ed.), Obras de don Pedro Calderón de la Barca, vol. III. Madrid: Atlas (Biblioteca de Autores Españoles, t. 12), pp. 507-530.

Calderón de la Barca, Pedro (1963). Eco y Narciso, Charles V. Aubrun (ed.). Paris: Centre de recherches de l'Institut d'Études Hispaniques.

Calderón de la Barca, Pedro (2011a). A secreto agravio secreta venganza, Erik Coenen (ed.). Madrid: Cátedra, 2011.

Calderón de la Barca, Pedro (2011b). La dama duende, Jesús Pérez Magallón (ed.). Madrid: Cátedra.

Carvallo, Luis Alfonso de (1997). Cisne de Apolo, Alberto Porqueras Mayo (ed.). Kassel: Reichenberger.

Cervantes, Miguel de (1998). El ingenioso hidalgo Don Quijote de la Mancha, Francisco Rico (ed). Barcelona: Instituto Cervantes, 2 vols. Accesible en: $<$ http://cvc.cervantes. es/literatura/clasicos/quijote/>.

Claramonte, Andrés de (2010). La estrella de Sevilla, en Alfredo Rodríguez López-Vázquez (ed.), La estrella de Sevilla, El gran rey de los desiertos. Madrid: Cátedra, pp. 141-315.

López Pinciano, Alonso (1998). Philosophía antigua poética, José Rico Verdú (ed.). Madrid: Biblioteca Castro.

Moreto, Augustín (1971). El desdén con el desdén (Las galeras de la honra, Los oficios), Francisco Rico (ed.). Madrid: Castalia.

Rojas Zorrilla, Francisco de (1952). También la afrenta es veneno, en Comedias escogidas de don Francisco de Rojas Zorrilla, Ramón de Mesonero Romanos (ed.). Madrid: Atlas (Biblioteca de Autores Españoles, t. 54), pp. 585-602.

Rojas Zorrilla, Francisco de (2007). Donde hay agravios no hay celos, Felipe B. Pedraza Jiménez y Milagros Rodríguez Cáceres (ed.), en Felipe B. Pedraza Jiménez y Rafael González Cañal (dir.), Elena E. Marcello (coord.), Obras completas, vol. I (Primera parte de comedias). Cuenca: Ediciones de la Universidad de Castilla-La Mancha, pp. 309-415.

Rojas Zorrilla, Francisco de (2009a). Los celos de Rodamonte, Manuel Delicado, Ana Isabel Zapata y Elena Marcello (ed.), en Felipe B. Pedraza Jiménez y Rafael González 
Cañal (dir.), Juan José Pastor (coord.), Obras completas, vol. II (Primera parte de comedias). Cuenca: Ediciones de la Universidad de Castilla-La Mancha, pp. 443-586.

Rojas Zorrilla, Francisco de (2009b). Persiles y Sigismunda, María Ángeles García GarcíaSerrano (ed.), en Felipe B. Pedraza Jiménez y Rafael González Cañal (dir.), Juan José Pastor (coord.), Obras completas, vol. II (Primera parte de comedias). Cuenca: Ediciones de la Universidad de Castilla-La Mancha, pp. 165-297.

\section{BIBLIOGRAFÍA CITADA}

Abel, Lionel (1965). Metateatro: una nuova interpretazione dell'arte drammatica. Milano: Rizzoli.

Abuín González, Á. (1996). «Juego, distancia y público. Sobre el concepto de metateatro» en Darío Villanueva y Fernando Cabo Aseguinolaza (ed.). Paisaje, juego y multilingüismo. Santiago de Compostela: Universidad de Santiago de Compostela, Consorcio de Santiago de Compostela, vol. 2, pp. 13-26.

Andres-Suárez, Irene (1997). «La autorreferencialidad en el teatro español del Siglo de Oro», en Irene Andres-Suárez, José Manuel López de Abiada y Pedro Ramírez Molas (ed.). El teatro dentro del teatro: Cervantes, Lope, Tirso y Calderón. Madrid: Verbum, pp. 11-29.

Badui de Zogbi, María Banura (2008). «El teatro, una constante estética en la obra de Cervantes», en José Manuel Lucía Megías y José Manuel Bendersky (ed.), Don Quijote en Azul. Actas de la I Jornadas Internacionales Cervantinas, Azul, 21-22 de abril de 2007. Madrid: Centro de Estudios Cervantinos, pp. 187-206.

Balestrino, Graciela (2011). «Calderón y el metateatro: abismación, trampantojo y apoteosis del comediante en Mojiganga del mundinovo», Teatro de palabras. Revista sobre teatro áureo. 5, pp. 119-141.

Barbagallo, Antonio (2001). «El Quijote: verosimilitud en la ficción o la ficción de la verdad», en Antonio Pablo Bernat Vistarini (ed.), Volver a Cervantes: actas del IV Congreso Internacional de la Asociación de Cervantistas, Lepanto 1/8 de octubre de 2000. Palma: Universitat de les Illes Balears, pp. 553-572.

Barone, Lavinia (2012). La figura del gracioso nel teatro di Pedro Calderón de la Barca. Pamplona: Servicio de publicaciones de la Universidad de Navarra.

Blanco, Mercedes (2004). «Gracián y el método», en Sebastian Neumeister (ed.), Baltasar Gracián: antropología y estética, Actas del II Coloquio Internacional (Berlín, 4-7 de octubre de 2001). Berlín: Verlag Walter Frey, pp. 35-61.

Borrego Gutiérrez, Esther (2005). «Bibliografía comentada sobre el gracioso del teatro áureo español (1993-2004)», en Luciano García Lorenzo (ed.), La construcción de un personaje: el gracioso. Madrid: Fundamentos, pp. 441-459.

Bustos Táuler, Álvaro (2014). «"Sonriéndome estoy”: Juan del Encina y sus pastores ante la tradición cómica y dramática», en José María Díez Borque (dir.), Hacia el gracioso: comicidad en el teatro español del siglo XVI. Madrid: Visor Libros, pp. 15-47.

Casalduero, Joaquín (1970). Sentido y forma del Quijote. Madrid: Ínsula.

Dällenbach, Lucien (1994). Il racconto speculare: saggio sulla mise en abyme. Parma: Pratiche Editrice.

Devoto, Daniel (1979). «Teatro y antiteatro en las comedias de Calderón», en Les cultures ibériques en devenir. Essais publiés en hommage à la mémoire de Marcel Bataillon (1895-1977). París: Fondation Singer-Polignac, pp. 313-344. 
Díaz-Plaja, Guillermo (1963). Cuestión de límites. Cuatro ejemplos de estéticas fronterizas (Cervantes, Velázquez, Goya, el cine). Madrid: Revista de Occidente.

Díez Borque, José María (1976). Sociología de la comedia española del siglo XVII. Madrid: Cátedra.

Díez Borque, José María (dir.) (2014). Hacia el gracioso: comicidad en el teatro español del siglo XVI. Madrid: Visor Libros.

Fischer, Susan L. (1981). «Lope's El castigo sin venganza and the Imagination», Kentucky Romance Quarterly, 28, pp. 23-36.

Forestier, Georges (1981). Le théâtre dans le théâtre. Sur la scène française de XVII siècle. Genève: Libraire Droz S.A.

Gambin, Felice (2001). «Baltasar Gracián: ingenio caprichoso de la filosofía», Insula: revistas de letras y ciencias humanas. 655-656, pp. 23-24.

García Lorenzo, Luciano (ed.) (2005). La construcción de un personaje: el gracioso. Madrid: Fundamentos.

Gómez, Jesús (1999). «Alusiones metateatrales en las comedias de Lope de Vega», Boletín de la Real Academia Española. 79 (277), pp. 221-247.

Gómez, Jesús (2002). «Precisiones etimológicas sobre "figura del donaire" y "gracioso" (siglos XVI-XVII)», Boletín de la Real Academia Española. 82 (286), pp. 233-257.

Gómez, Jesús (2005). «Una visión sobre el personaje del gracioso en la crítica actual», en Luciano García Lorenzo (ed.), La construcción de un personaje: el gracioso. Madrid: Fundamentos, pp. 11-22.

Gómez, Jesús (2006). La figura del donaire o el gracioso en las comedias de Lope de Vega. Sevilla: Alfar.

Hatzfeld, Helmut (1964). Estudios sobre el Barroco. Madrid: Gredos.

Hermenegildo, Alfredo (1995). «Polilla: El desdén, con el desdén, de Agustín Moreto», en Juegos dramáticos de la locura festiva. Pastores, simples, bobos y graciosos del teatro clásico español. Palma de Mallorca: Olañeta, pp. 245-265.

Hermenegildo, Alfredo (1996). «El personaje espectador: teatro en el teatro del siglo XVII», Scriptura. 11, pp. 125-139.

Hermenegildo, Alfredo (1999). «Mirar en la cadena: artificios de metateatralidad cervantina», en Catherine Poupeney Hart, Alfredo Hermenegildo y César Oliva Olivares (ed.), Cervantes y la puesta en escena de la sociedad de su tiempo (actas del Coloquio de Montreal 1997). Murcia: Universidad de Murcia, pp. 77-92.

Hermenegildo, Alfredo (2002). «Tensiones entre la ficción y la realidad: estudios sobre metateatralidad calderoniana», en Francisco Domínguez Matito y Julián Bravo Vega (ed.), Calderón entre veras y burlas. Actas de las II y III jornadas de Teatro clásico de la Universidad de la Rioja. Universidad de la Rioja: Servicio de Publicaciones, pp. 161-176.

Hermenegildo, Alfredo (2003). «Usos de la metateatralidad: los pasos de Lope de Rueda», Signos literarios y lingüísticos. 5: 2, pp. 13-31.

Hernández-Araico, Susana (1986). «El gracioso y la ruptura de la ilusión dramática», Imprévue. 1, pp. 61-73.

Hornby, Richard (1986). Drama, metadrama, and perception. Lewisburg, PA: Bucknell University Press.

Imperiale, Louis (1994). «El auctor ante sus personajes en La Lozana andaluza», en Juan Villegas (ed.), Lecturas y relecturas de textos españoles, latinoamericanos y US latinos. Actas del XI congreso de la Asociación Internacional de Hispanistas, Irvine, California, 24-29 de agosto de 1992, vol. V. Irvine: Asociación Internacional de Hispanistas, pp. 59-67. 
José Prades, Juana de (1963). Teoría sobre los personajes de la comedia nueva, en cinco dramaturgos. Madrid: Consejo Superior de Investigaciones Científicas.

Lázaro Carreter, Fernando (1987). «Funciones de la figura del donaire en el teatro de Lope», en Ricardo Domenech (ed.), El castigo sin venganza y el teatro de Lope de Vega. Madrid: Cátedra, pp. 31-48.

Ley, Charles David (1954). El gracioso en el teatro de la península (siglos XVI-XVII). Madrid: Revista de Occidente.

Limentani Virdis, Caterina (1981). Il quadro e il suo doppio. Effetti di specularitá narrativa nella pittura fiamminga e olandese. Modena: STEM-Mucchi.

Lobato, María Luisa (1994). «Ensayo de una bibliografía anotada del gracioso en el teatro español del Siglo de Oro», Criticón. 60, pp. 149-170.

Lobato, María Luisa (2005). «Mosqueteros de la paz, árbitros de la comedia: las fórmulas del captatio benevolentiae en boca del gracioso», en Luciano García Lorenzo (ed.), La construcción de un personaje: el gracioso. Madrid: Fundamentos, pp. 252-276.

Lotman, Jurij M. (1985). La struttura del testo. Milano: Mursia.

Maestro, Jesús G. (2005). «Cervantes y el teatro del Quijote», Hispania. 88:1, pp. 41-52, doi: https://doi.org/10.2307/20063074.

Martín Morán, José Manuel (1986). «Los escenarios teatrales del Quijote», Anales Cervantinos. 24, pp. 27-46.

Martínez-Bonati, Félix (1995). El Quijote y la poética de la novela. Alcalá de Henares: Centro de Estudios Cervantinos.

Martínez San Juan, Miguel Angel (2004). «Verosimilitud, crisol de realidades y ficciones», en Alicia Villar Lecumberri (ed.), Peregrinamente peregrinos: actas de V Congreso Internacional de la Asociación de Cervantistas, Lisboa, Fundaçao Calouste Gulbenkian, 1-5 septiembre 2003. Alcalá de Henares: Asociación de Cervantistas, vol. I, pp. 593-616.

McCurdy, Raymond R. (1976). «More on "The Gracioso Takes the Audience into His Confidence": The Case of Rojas Zorrilla», Bulletin of the Comediantes. 8: 1, pp.14-16, doi: https://doi.org/10.1353/boc.1956.0012.

McCurdy, Raymond R. y Rodríguez, Alfred (1980). «El gran teatro del mundo y el Quijote del 1615», Cuadernos del Sur. 13, pp. 123-130.

Miñana, Rogelio (2002). La verosimilitud en el Siglo de Oro: Cervantes y la novela corta. Newark: Juan de la Cuesta.

Montero Reguera, José (1997). El Quijote y la crítica contemporánea. Alcalá de Henares: Centro de Estudios Cervantinos.

Montesinos, José F. (1967). Estudios sobre Lope. Salamanca: Anaya.

Morón Arroyo, Ciriaco (1983). «La ironía de la escritura en Calderón», en Karl-Hermann Körner y Dietrich Briesemeister (ed.), Aureum saeculum hispanum. Festschrift für Hans Flasche zum 70. Gerburstag. Wiesbaden: Franz Steiner Verlag GMBH, pp. 217230.

Núñez Ronchi, Ana (2005). «“Así se escribe la historia”: verdad y verosimilitud en Los trabajos de Persiles y Sigismunda: historia septentrional», Didáctica (Lengua y Literatura). 17, pp. 217-234.

Orozco Díaz, Emilio (1962). «La literatura religiosa y el Barroco (en torno al estilo de nuestros escritores místicos y ascéticos)», Revista de la Universidad de Madrid. 12: 42-43, pp. 411-477.

Orozco Díaz, Emilio (1969). El teatro y la teatralidad del Barroco (Ensayo de introducción al tema). Barcelona: Planeta.

Ortega y Gasset, José (1966). La deshumanización del arte, en Obras completas, t. III (1917-1928). Madrid: Revista de Occidente, pp. 353-386. 
Pailler, Claire (1980). «El gracioso y los "guiños" de Calderón: apuntes sobre "autoburla" e ironía crítica», en Risa y sociedad en el teatro español del Siglo de Oro. Actes du $3^{e}$ colloque du Groupe d'etudes sur le théâtre espagnol. Toulouse 31 janvier-2 février 1980. Paris: CNRS, pp. 33-48.

Percas de Ponseti, Helena (1975). Cervantes y su concepto del arte. Madrid: Gredos, 2 vols.

Pérez, Miguel José y Enciso Orellana, Julia (1999). «Cervantes entre la realidad y la ficción de su propia obra (Una meditación personal en torno al capítulo 3 de la Segunda Parte)», Didáctica (Lengua y Literatura). 11, pp. 111-122.

Pérez, Ramón Manuel (2011). «Los filos de la verosimilitud: Cervantes y la ficción moral del siglo XVII», en Christoph Strosetzki (ed.), Visiones y revisiones cervantinas: actas selectas del VII Congreso Internacional de la Asociación de Cervantistas. Alcalá de Henares: Centro de Estudios Cervantinos, pp. 705-716.

Reed, Cory A (1994). «Entremés and Novel: Comic Theatricality in Don Quijote», en Cervantes. Estudios en la víspera de su centenario, vol. I. Kassel: Edition Reichenberger, pp, 197-213.

Ricapito, Joseph V. (2003). «La teatralidad en la prosa del Quijote», Theatralia: revista de poética del teatro. 5, pp. 315-330.

Riley, Edward C. (1989). Teoría de la novela en Cervantes. Madrid: Taurus, 1989.

Rodríguez López-Vázquez, Alfredo (2011). «Epiteatro, hipoteatro y metateatro», Teatro de palabras. Revista sobre teatro áureo. 5, pp. 143-161.

Rubiera Fernández, Javier (2005). «Función cómica y funciones dramáticas del gracioso en la Hija del aire», en Luciano García Lorenzo (ed.), La construcción de un personaje: el gracioso. Madrid: Fundamentos, pp. 225-249.

Ruffinatto, Aldo (1985). Semiotica ispanica: cinque esercizi. Alessandria: Edizioni dell'Orso.

Ruiz Ramón, Francisco (2005). «La figura del donaire como figura de la mediación (el bufón calderoniano)», en Luciano García Lorenzo (ed.), La construcción de un personaje: el gracioso. Madrid: Fundamentos, pp. 203-224.

Sáez, Adrián J. (2015). «Entre versiones anda el juego: la reescritura del gracioso en los dramas de Calderón», en Germán Vega García-Luengo, Héctor Urzáiz Tortajada y Pedro Conde Parrado (ed.), El patrimonio del teatro clásico español: actualidad y perspectivas. Homenaje a Francisco Ruiz Ramón. Actas selectas del Congreso del TC/12, Olmedo, 22 al 25 de julio de 2013. Olmedo/Valladolid: Ayuntamiento de Olmedo/Ediciones Universidad de Valladolid, pp. 601-617.

Segre, Cesare (1979). Semiotica filologica. Testo e modelli culturali. Torino: Einaudi.

Serés, Guillermo (2011). «Consideraciones metateatrales en algunas comedias de Lope de Vega», Teatro de palabras. Revista sobre teatro áureo. 5, pp. 87-117.

Sosa, Marcela Beatriz (2010). «Entre bobos (no) anda el juego: convenciones genéricas, metateatro y efecto de recepción en la comedia de Rojas Zorrilla», Castilla. Estudios de literatura. 1 , pp. 60-71.

Strappini, Lucia (2003). La tragedia del buffone. Percorsi del comico e del tragico nel teatro del XVII secolo. Roma: Bulzoni.

Syverson-Stork, Jill (1987). Teatrical Aspects of the Novel: A Study of Don Quijote. Valencia: Albatros Hispanófila.

Valbuena Prat, Ángel (1941). Calderón: su personalidad, su arte dramático, su estilo y sus obras. Barcelona: Editorial Joventud S.A.

Van Doren, Mark (1962). La profesión de Don Quijote. México: Fondo de Cultura Económica. 
Vara López, Alicia; Vila Carneiro, Zaida (2015). «"Y con esto se da fin”: fórmulas estereotipadas y metateatralidad en los cierres de las comedias calderonianas», Hispanic research journal. 16: 6, pp. 507-522, doi: https://doi.org/10.1080/14682737.2015.1129 835.

Vega, Lope de (2004). Las bizarrías de Belisa, Enrique García Santo-Tomás (ed.). Madrid: Cátedra.

Vélez-Sainz, Julio (2009). «Hacia la construcción del gracioso: Carnaval y metateatralidad en los pastores de Bartolomé Torres Naharro», Tejuelo. 6, pp. 33-43.

Villarino, Marta (2001). «Lope de Vega, escritura y metateatro en La portuguesa y dicha del forastero», en Christoph Strosetzki (ed.), Actas del V congreso de la Asociación Internacional Siglo de Oro. Münster 1999. Madrid-Frankfurt: Iberoamericana-Vervuert, pp.1341-1349.

Ynduráin, Francisco (1969). «Cervantes y el teatro», en Relección de los clásicos. Madrid: Editorial prensa española, pp. 87-112.

Zoppi, Federica (2016a). «Los libros de caballerías, el Quijote y la lectura», Historias fingidas. 4, pp. 167-188.

Zoppi, Federica (2016b). Risa, sonrisa, ironía en el Quijote. Burlas de acción y burlas de palabra. Vigo: Academia del Hispanismo.

Recibido: 17 de noviembre de 2016

Aceptado: 22 de junio de 2017 